\title{
ANTIMICROBIAL ACTIVITY OF CHROMOLAENA ODORATA AGAINST WOUND INFECTION
}

\author{
Dr.R. Mahenthiran \\ Department of Microbiology, \\ Dr.N.G.P. Arts and Science College \\ Coimbatore, India \\ Poovendiran $\mathrm{P}$ \\ PG student, Research department of \\ Microbiology, Dr.N.G.P. Arts and Science \\ College \\ Coimbatore, India \\ Sudharsan K \\ PG student, Research department of \\ Microbiology, Dr.N.G.P. Arts and Science \\ College \\ Coimbatore, India
}

\begin{abstract}
This plant extract that was well-tried to be effectively used as a natural different supply of stop and cure the wound accustomed discover different bioactive natural product that will function lead for the event of latest pharmaceutical drug. Hence, this plant may function an alternate medication while not facet effects and additionally they might more be vulnerable bacterium were Escherichia coli. The recent ethanolic extract solely suppressed the expansion of staph aureus. dry ethanolic extract suppressed the expansion of staph aureus, bacteria genus spp, E. coli, Klebsiella. Spp. the foremost properties by agar well diffusion technique mistreatment Mueller-Hinton Agar ( $\mathrm{AHM})$ on human infective bacterium. The dry and recent ethanolic extracts of the leaves of Chromolaena odorata were studied for in vitro antimicrobial
\end{abstract}

KEYWORDS: C. odorata, Antimicrobial activity, wound infection, MIC

\section{INTRODUCTION}

Pyogenic infection is associated in nursing infection characterized by severe native inflammation, typically with pus formation, generally caused by the pyogenic organism. Humans area unit the natural host for many bacterial species that colonize the skin as normal flora. Skin infections are common and may be caused by bacteria, fungi or viruses. Human infection, significantly those involving the skin and mucosal membrane surfaces might cause serious complications. The foremost common bacterium that as a result of wound infections are Staphylococcus aureus,

\author{
Sornambiga Ravi \\ PG student, Research department of \\ Microbiology, Dr.N.G.P. Arts and Science \\ College \\ Coimbatore, India \\ Archana S Nair \\ PG student, Research department of \\ Microbiology, \\ Dr.N.G.P. Arts and Science College \\ Coimbatore, India \\ Vishnu Priyanka K \\ PG student, Research department of \\ Microbiology, Dr.N.G.P. arts and Science College \\ Coimbatore, India
}

Staphylococcus epidermidis, Streptococcus pyogenes, Pseudomonas aeruginosa, Klebsiella pneumoniae and Candida albicans.

$S$. epidermidis is an endemic organism, consisting of non-motile Gram-positive cocci, arranged in grape like clusters. The ability to makes biofilms on plastic devices may be a major virulence issue for $S$. epidermidis. It is part of the skin flora, and consequence part of human flora. It can also be found in the mucous membrane of humans and in animals. Traditional medicative plants area unit for the treatment of wound infection with unsafe effects in effects in body. Medicative plants are widely used to cure different infection and also used as a precursor for the synthesis of natural drugs. It is reported that 20 medicinal plants from hazard division have antimicrobial activity against some selective organisms such as Staphylococcus aureus, Staphylococcus epidermidis, Enterococcus faecalis, Salmonella, Pseudomonas aeruginosa and Escherichia coli. Chromolaena odorata belongs to the family of Asteraceae. It is used as a traditional medicinal plant to cure wounds, cuts, burns, soft tissue aberrations. It has wound healing property and also promotes blood coagulation. It is used to treat diabetes and effective against the diarrhea strains. The main aim of the study is to determine the efficacy of the plant extract Chromolaena odorata against the Pathology infective agent.

\section{OBJECTIVE}

- To isolate and characterise of wound infected samples. 
- To test the antibacterial activity of Chromolaena odorata against the wound infected pathogen.

- To find out MIC of isolated pathogens.

\section{MATERIALS AND METHODS}

\section{Collection of samples}

Completely different wound swab samples were collected for the isolation of pathology bacteria that infect the wounds.

\section{Isolation of organisms}

The collected samples were inoculated into blood agar and MacConkey's Agar. The inoculated media were incubated overnight at $37^{\circ} \mathrm{c}$ for 48 hours.

\section{Identification of organism}

The isolated organisms were known by following techniques (Berge's manual) of microscopic observation and cultural characteristics, biochemical characteristics.

\section{Microscopic observation}

\section{Gram's staining} obtained.

Gram's staining was performed for the colonies

\section{Cultural characterization}

The observed microorganisms were inoculated in to respective media and incubated at $37^{\circ} \mathrm{C}$.

\section{Biochemical characterization}

Biochemical characteristics were performed.

\section{Collection of Leaf}

\section{Collection and Storage of Plant Materials}

The leaves of $C$. odorata were collected from nearby areas. It was washed in running water to induce eliminate dirt particles and subjected to shade drying for concerning one week. Dried leaves were powdered with an electric mill. The sample were stored in an airtight container and tested for certain biologically active compounds.

\section{Organoleptic analysis of C. odorata}

The plant parts were organoleptically evaluated and examined for numerous sensory parameters like colour, appearance of the plant parts principally size and shape, external texture, fracture (granular, splintery, smooth) and external markings (furrow, wrinkles, ridges, annular, out growth) of the plant components. The fragrance, test for odour (aromatic, balsamic, camphorates, spicy, pleasant, irritating) and taste (sweet, bitter, sour, astringent, pungent, acidic, alkaline) were evaluated.

\section{Successive Solvent Extraction of plant materials}

The phytochemical constituents were extracted using successive solvent extraction method based on polarity. About 20 grams of grained leaves of $C$. odorata was separately mixed with $100 \mathrm{~mL}$ of solvent (Petroleum Benzene, Chloroform, Ethanol, Water) and subjected to occasional shaking for $24 \mathrm{~h}$. The plant extracts were filtered using Whatman No.1 filter paper. The filtrate was concentrated by evaporation at room temperature. During all the extraction with the next solvent, the residue was air dried completely to eliminate the trace of solvent used.

\section{Screening for Phytochemical Constituents}

The dried plant extracts were screened for the presence of phytoconstituents like alkaloids, saponins, terpenoids, glycosides, flavonoids, sterols and steroids, tannins, phenolic resin compounds, carbohydrates

\section{METHODOLOGY FOR THE LCMS ANALYSIS}

Sample: Chromolaena

\section{SPECIFICATIONS:}

Lc column : reverse phase c-18

Pump : spd 10 avp

Mobile phase : water\& methanol (50:50)

Ionization mode : electronic spray ionization/APCI

Mode : both positive and negative

Injection volume : 10microlitre

\begin{tabular}{|c|c|}
\hline Flow rate & $: 2 \mathrm{ml} / \mathrm{min}$ \\
\hline Column temperature & $: 250 \mathrm{c}$ \\
\hline Column & : Phenomenex rp 18 \\
\hline Column dimension & $: 25 \mathrm{~cm} \times 2.5 \mathrm{~mm}$ \\
\hline Lc detection & $: 254 \mathrm{~nm}$ \\
\hline $\begin{array}{l}\mathrm{M} / \mathrm{z} \text { range } \\
\text { for pos }\end{array}$ & : 50-800 for neg and 50-950 \\
\hline Software & : class v p integrated. \\
\hline Library & : Met win 2.0 \\
\hline
\end{tabular}




\section{ANTIBACTERIAL ACTIVITY OF $C$. ODERATA}

\section{Agar Well Diffusion Method}

The agar well diffusion method was wont to determine the expansion inhibition. The plant extracts were prepared at a concentration of two, $5,5,7.5,10 \mu \mathrm{g} / \mathrm{mL}$. The sterile Muller Hinton Agar was prepared and poured in sterile petri dishes and allowed to solidify. With the assistance of a sterile well cutter, $6 \mathrm{~mm}$ diameter wells were punctured with uniform spacing for various concentrations for every extract. The log phase culture broth was taken and swabbed over the plate using sterile cotton swab to get uniform lawn of culture. The wells were crammed with $10 \mu \mathrm{l}$ of the concentration of the plant extracts respectively. The plates were then incubated at $37^{\circ} \mathrm{C}$ for $24 \mathrm{~h}$ for bacteria and at room temperature for yeast.

Table-1 Morphological, Cultural, Physiological and Biochemical Characteristics of the Isolated Strains

\begin{tabular}{|c|c|c|c|c|c|c|c|c|}
\hline CHARACTERISTICS & $\begin{array}{l}\text { Sample } \\
1\end{array}$ & $\begin{array}{l}\text { Sample } \\
2\end{array}$ & $\begin{array}{l}\text { Sample } \\
3\end{array}$ & $\begin{array}{l}\text { Sample } \\
4\end{array}$ & $\begin{array}{l}\text { Sample } \\
5\end{array}$ & $\begin{array}{l}\text { Sample } \\
6\end{array}$ & $\begin{array}{l}\text { Sample } \\
7\end{array}$ & $\begin{array}{l}\text { Sample } \\
8\end{array}$ \\
\hline \multirow[t]{2}{*}{ Colony morphology } & $\begin{array}{l}\text { No } \\
\text { Gro } \\
\text { wth }\end{array}$ & $\begin{array}{l}\text { No } \\
\text { Growth }\end{array}$ & $\begin{array}{l}\text { Golden } \\
\text { yellow } \\
\text { coloured } \\
\text { colonies }\end{array}$ & & $\begin{array}{l}\text { Circular, } \\
\text { Mucoid, } \\
\text { Greyish } \\
\text { white }\end{array}$ & $\begin{array}{l}\begin{array}{l}\text { Light } \\
\text { golden }\end{array} \\
\text { yellow, } \\
\text { surroun } \\
\text { ded by } \\
\text { clear } \\
\text { zone } \\
\text { (beta } \\
\text { hemolys } \\
\text { is). }\end{array}$ & $\begin{array}{l}\text { Light } \\
\text { golden } \\
\text { yellow, } \\
\text { surrounde } \\
\text { d by clear } \\
\text { zone (beta } \\
\text { hemolysis) } \\
\text { - }\end{array}$ & \\
\hline & 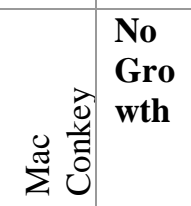 & $\begin{array}{l}\text { No } \\
\text { Growth }\end{array}$ & $\begin{array}{l}\text { Circular, } \\
\text { Pink, } \\
\text { Convex }\end{array}$ & & $\begin{array}{l}\text { Circular, } \\
\text { mucoid, } \\
\text { Pink Red, } \\
\text { Convex }\end{array}$ & $\begin{array}{l}\text { Circular } \\
\text {, Pink, } \\
\text { Convex }\end{array}$ & $\begin{array}{l}\text { Circular, } \\
\text { Pink, } \\
\text { Convex }\end{array}$ & \\
\hline Gram's staining & NA & NA & G+ & G - & - & G+ & G+ & - \\
\hline Indole test & NA & NA & - & + & - & - & - & - \\
\hline MR & NA & NA & + & + & - & + & + & - \\
\hline VP & NA & NA & + & - & + & + & + & + \\
\hline Citrate & NA & NA & + & - & + & + & + & + \\
\hline Oxidase & NA & NA & - & - & - & - & - & + \\
\hline Catalase & NA & NA & + & + & + & + & + & + \\
\hline TSI & NA & NA & A+G- & $\begin{array}{l}\text { Acid Butt, } \\
\text { Acid Slant }\end{array}$ & $\begin{array}{l}\text { Acid Butt, } \\
\text { Acid slant }\end{array}$ & $A+G-$ & A+G- & $\begin{array}{l}\text { Alkaline } \\
\text { Butt, } \\
\text { Alkaline } \\
\text { Slant }\end{array}$ \\
\hline Motility & NA & NA & - & $\mathbf{A}+\mathbf{G}-$ & A+G- & A+G- & A+G- & + \\
\hline
\end{tabular}


The antimicrobial activity of ordinary antimicrobial agents like Ampicillin, Bacitracin, Ciprofloxacin, Gentamicin and Levofloxacin were tested against wound infecting microorganisms. Their sensitivity pattern was compared using standard antibiogram chart.

\section{Determination of Minimum Inhibitory Concentration (MIC)}

The minimum inhibitory concentration (MIC) of all the Supernatant decided for every of the test organisms in triplicates at varying concentration of $1 \%, 3 \%$, and $5 \%$. To get this varying concentration added $10 \mathrm{ml}$ of peptone water. A tube containing peptone water only was seeded with the test organism to function control. All the tubes were then incubated at $37^{\circ} \mathrm{C}$ for twenty-four hours then examined for growth by observing turbidity.

\section{PREPERATION OF DISC}

Disc cutting to the gauze in circular shape size $(6 \mathrm{~mm})$. Then disc is dipped in already prepared leaf extraction (petroleum, ethanol. etc.). After 5 minutes disc allow to air dry.

\section{DISC DIFFUSION METHOD}

18 hours broth cultures of every test organism were inoculated into Muller Hinton agar using sterile cotton swab. The three concentrations of discs dipped in each test plate using sterile forceps. Then the plates were incubated at $37^{\circ} \mathrm{C}$ for twenty-four hours. After the incubation period, the diameter of inhibition zones of every disc was measured.

Isolation and identification of organism.

From the collected samples, the subsequent organisms were isolated.

\section{Staphylococcus aureus \\ 2. Pseudomonas spp \\ 3. E. Coli \\ 4. Klebsiella. Spp.}

Antimicrobial activity of $\boldsymbol{C}$. Odorata against wound infecting pathogens

The antimicrobial activity of $C$. Odorata extracts were assayed by Agar well diffusion method. The extracts of the plant $C$. odorata showed higher activity against the wound infecting pyrogens. While comparing all the extracts, Ethanol and Chloroform extracts of $C$. odorata had higher activity against the wound infecting pathogens. Water and Petroleum ether extracts showed less activity against the wound infecting pathogen. The zone of inhibition of the plant extracts were compared with the commercial antibiotics and revealed that the plant components had high inhibitory propertyies

Antimicrobial activity of Chromolaena odorata against wound infecting pathogen.
Table -2: Petroleum benzene Extract of $C$. Odorata

\begin{tabular}{|l|l|l|l|l|}
\hline \multirow{2}{*}{$\begin{array}{l}\text { ORGANISM } \\
\text { S }\end{array}$} & \multicolumn{4}{|l|}{ ZONE OF INHIBITION } \\
\cline { 2 - 5 } & $\begin{array}{l}10 \\
\mathrm{mg} / \mathrm{m}\end{array}$ & $\begin{array}{l}7.5 \\
\mathrm{mg} / \mathrm{m} \\
\mathrm{l}\end{array}$ & $\begin{array}{l}\mathbf{5} \\
\mathrm{mg} / \mathrm{m} \\
\text { l }\end{array}$ & $\begin{array}{l}\mathbf{2 . 5} \\
\mathrm{mg} / \mathrm{m} \\
\text { l }\end{array}$ \\
\hline S. aureus & 15 & 13 & 11 & - \\
\hline E. coli & 13 & 11 & 8 & 8 \\
\hline Klebsiella spp & 12 & 11 & 8 & 8 \\
\hline $\begin{array}{l}\text { S. aureus } \\
\text { S. aureus }\end{array}$ & 14 & 13 & 11 & 11 \\
\hline $\begin{array}{l}\text { Pseudomonas } \\
\text { spp }\end{array}$ & 10 & 14 & 13 & 11 \\
\hline
\end{tabular}

Table-3 Ethanol Extract of $C$. Odorata

\begin{tabular}{|c|c|c|c|c|}
\hline \multirow[b]{2}{*}{$\begin{array}{l}\text { ORGANISM } \\
\mathrm{S}\end{array}$} & \multicolumn{4}{|c|}{ ZONE OF INHIBITION } \\
\hline & $\begin{array}{l}10 \\
\mathrm{mg} / \mathrm{m} \\
\mathrm{L}\end{array}$ & $\begin{array}{l}7.5 \\
\mathrm{mg} / \mathrm{m} \\
1\end{array}$ & $\begin{array}{l}5 \\
\mathrm{mg} / \mathrm{m} \\
1\end{array}$ & $\begin{array}{l}2.5 \\
\mathrm{mg} / \mathrm{m} \\
\mathrm{l}\end{array}$ \\
\hline S. aureus & 20 & 14 & 11 & 8 \\
\hline E. coli & 11 & 8 & - & - \\
\hline Klebsiella spp & 12 & 8 & 6 & - \\
\hline S. aureus & 21 & 16 & 14 & 8 \\
\hline S. aureus & 12 & 15 & 14 & 11 \\
\hline $\begin{array}{l}\text { Pseudomonas } \\
\text { spp }\end{array}$ & 13 & 10 & - & - \\
\hline
\end{tabular}

Table-4: Distilled Water Extract of $C$. Odorata

\begin{tabular}{|l|l|l|l|l|}
\hline \multirow{2}{*}{ ORGANISMS } & \multicolumn{4}{|l|}{ ZONE OF INHIBITION } \\
\cline { 2 - 5 } & $\begin{array}{l}10 \\
\mathrm{mg} / \mathrm{mL}\end{array}$ & $\begin{array}{l}7.5 \\
\mathrm{mg} / \mathrm{ml}\end{array}$ & $\begin{array}{l}\mathbf{5} \\
\mathrm{mg} / \mathrm{ml}\end{array}$ & $\begin{array}{l}2.5 \\
\mathrm{mg} / \mathrm{ml}\end{array}$ \\
\hline S. aureus & 17 & 12 & 10 & - \\
\hline E. coli & 16 & 12 & - & - \\
\hline Klebsiella spp & 14 & 9 & - & - \\
\hline S. aureus & 15 & 12 & 10 & - \\
\hline S. aureus & 16 & 12 & 10 & - \\
\hline
\end{tabular}




\begin{tabular}{|l|l|l|l|l|}
\hline $\begin{array}{l}\text { Pseudomonas } \\
\text { spp }\end{array}$ & 14 & 12 & 10 & - \\
\hline
\end{tabular}

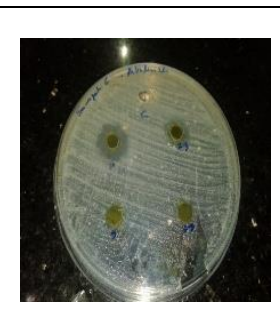

A

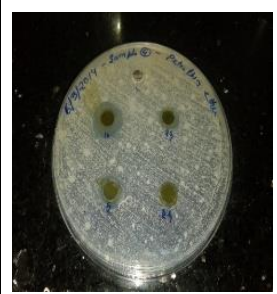

$\mathrm{D}$

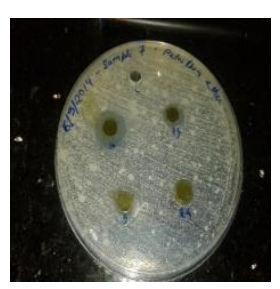

B

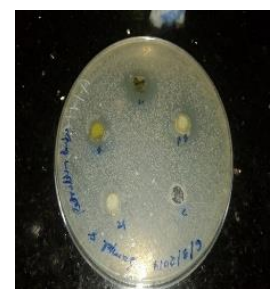

E

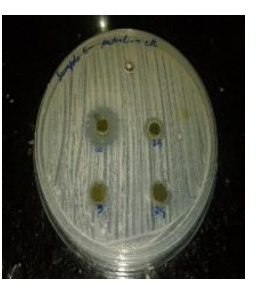

$\mathrm{C}$

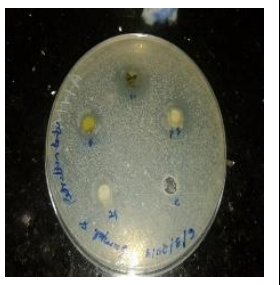

F

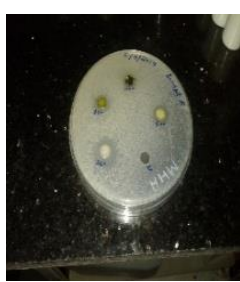

A

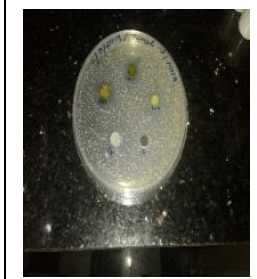

$\mathrm{D}$

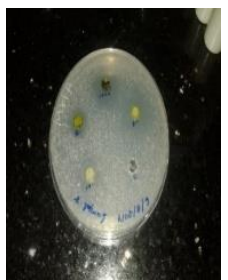

B

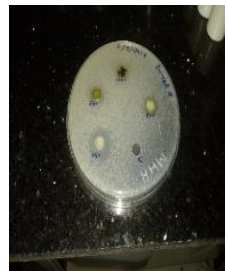

E

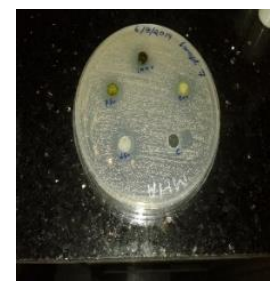

C

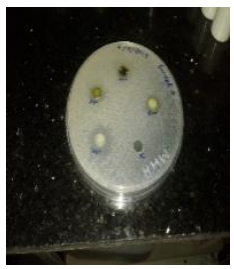

F

Fig. 2: Antimicrobial Activity of Chloroform Extract of Chromolaena Odorata Against Wound Infecting Pathogens(a)Staphylococcus aureus, (b) E. coli, (c) Klebsiella, (d)Staphylococcus aureus, (e) Staphylococcus aureus, (f) Pseudomonas spp.

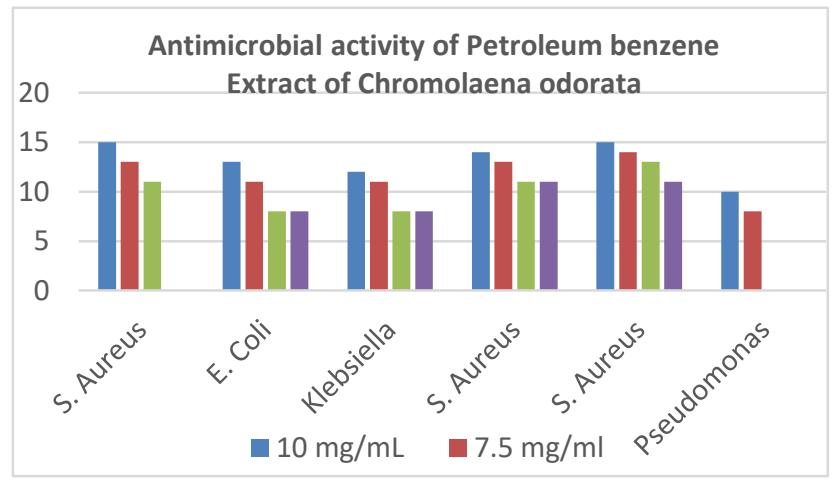

Antimicrobial activity of Ethanol Extract of Chromolaena odorata

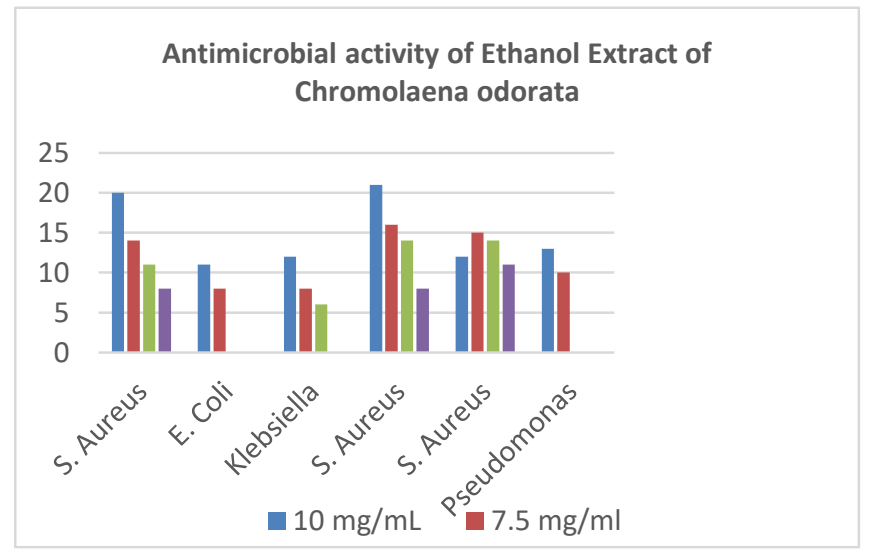




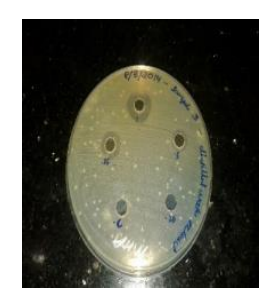

A

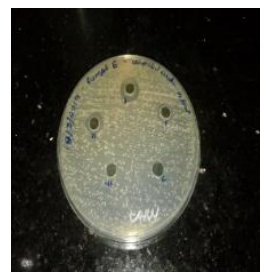

$\mathrm{E}$

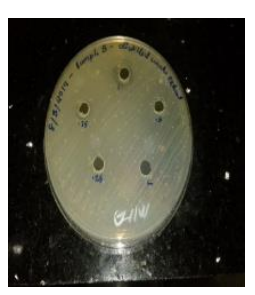

B

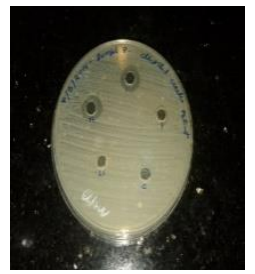

$\mathrm{F}$

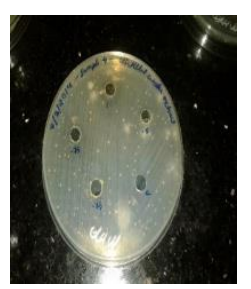

C

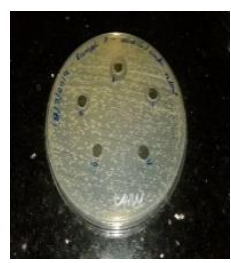

$\mathrm{G}$
Fig. 3: Antimicrobial Activity of distilled water Extract of Chromolaena Odorata Against Wound Infecting Pathogens(a)Staphylococcus aureus, (b) E. coli, (c) Klebsiella, (d)Staphylococcus aureus, (e) Staphylococcus aureus, (f) Pseudomonas spp

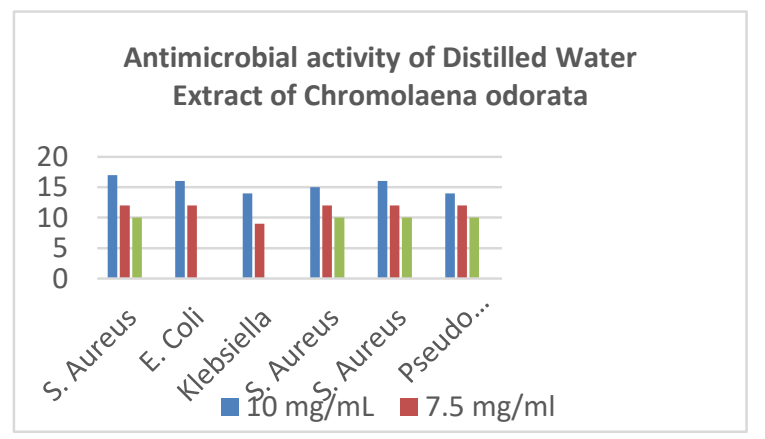

\section{RESULT AND DISCUSSION}

The antimicrobial assessment of $C$. Odorata against the wound infecting pathogens reveals that the phytoconstituents has high antimicrobial property which was compared and confirmed with commercial antibiogram. Since the drug resistance nature of the pyrogens increases day by day this herbal remedy will function an alternate medicine without side effects. These extracts were used as medicine for pyogenic infection rather than using synthetic antibiotics and medicines. These plants are often wont to discover bioactive natural products that function lead for the event of latest phytopharmaceuticals.

\section{ACKNOWLEDGMENT}

The authors are thankful and gratefully acknowledge to our college funding department DBT-Star scheme,
DST-FIST scheme, and to the management of Dr.N.G.P. Arts and Science college, Coimbatore, our college Principal, Deans of Dr.N.G.P. Arts and Science college, Coimbatore also as well as all faculty members and our guide, Department of microbiology Dr.NGP.Arts and science college, Coimbatore for providing constant support for this complete work. (Communication number: DrNGPASC 2020-21 BS047).

\section{REFERANCE}

[1] Ayton M. Wound care (1985): wounds that won't heal. Nurs Times; 81(46): suppl 16-19.

[2] Falanga V, Grinnell F, Gilchrest B, Maddox YT, Moshell A, J Invest Dermatol (1994). Workshop on the pathogenesis of chronic wounds.; 102(1): 12527.

[3] Kingsley A. (2001). A proactive approach to wound infection. Nurs Stand; 15(30): 50-54, 56, 58.

[4] Cooper R, Kingsley A, White R. (2003) Wound Infection and Microbiology.: Medical Communications (UK) Ltd for Johnson \& Johnson Medical.

[5] English MP, Smith RJ, Harman RR $\mathrm{Br} J$ Dermatol (1971). The fungal flora of ulcerated legs.; 84(6): 567-81.

[6] "Chromolaena odorata". Flora of North America.

[7] Schmidt GJ, Schilling EE, (May 2000) Phylogeny and Biogeography of Eupatorium (Asteraceae: Eupatorieae) Based on Nuclear ITS Sequence, American Journal of Botany (Botanical Society of America), 87 (5): 716-726.

[8] Struhsaker TT, Struhsaker PJ, Siex KS, (May 2005), "Conserving Africa's rain forests: problems in protected areas and possible solutions" (PDF). Biological Conservation, 123 (1): 45-54.

[9] Raimundo RLG, Fonseca RL, Schachetti-Pereira R, Peterson AT \& Thomas Michael Lewinsohn, (May 2005), active and Exotic Distributions of Siamweed (Chromolaena odorata) Modeled Using the Genetic Algorithm for Rule-Set Production, Weed Science, 55 (1): 41-48.

[10] Fu PP, Yang YC, Xia Q, Chou MC, Cui YY, Lin G, (2002), "Pyrrolizidine alkaloids-tumorigenic components in Chinese herbal medicines and dietary supplements", Journal of Food and Drug Analysis, 10(4), 198-211.

[11] Rachel Cruttwell, McFadyen and Bryce Skarratt, (1996), Potential distribution of Chromolaena odorata (siam weed) in Australia, Africa and Oceania, Agriculture, Ecosystems and Environment, 59(1-2), 89-96.

[12] Vanderwoude et al.

(2005), www.issg.org/database/species/ecology 
[13] Liogier, H.A. (1997). Descriptive flora of Puerto Rico and adjacent islands. Vol. 5. Editorial de la Universidad de Puerto Rico, San Juan, PR. 436 p.

[14] Liogier, H.A. (1990). Plantas medicinales de Puerto Rico y del Caribe. Iberoamericana de Ediciones, Inc., San Juan, PR. 566 p.

[15] Pacific Island Ecosystems at Risk. (2001).

Invasive plant species: Chromolaena odorata (L.) King \& Robinson, Asteraceae.

http://www.hear.org/pier/chodo.htm. 3 p. 